pISSN : $2301-8968$

JEKT $14[1]: 173-189$

eISSN : $2303-0186$

\title{
One Decade, 20 Percent Education Budget: How About Causality Between Education Success and Poverty?
}

Putu Yudy Wijaya

Ni Nyoman Reni Suasih

Universitas Hindu Indoneisa

Universitas Udayana

\begin{abstract}
In 2019, exactly one decade of the government expenditure on education in Indonesia (central and local government) was allocated 20 percent. The purpose of this study was to analyze the causality relationship between government budget on education, education success (proxied by the mean years of schooling), and poverty (proxied by the number of poor people) in Indonesia. The data analyzed is secondary data, to be precise panel data from 34 provinces in Indonesia over a period of five years (20152019). The analysis technique used is the Granger Causality Test. The results showed that the government budget on education had a significant effect on the mean years of schooling and had a causal relationship with poverty. Meanwhile, poverty has been shown to affect the mean years of schooling. Based on the results of this analysis, it is for the government to consistently prioritize the budget for the education sector because it is proven to have an impact on education success and poverty alleviation. In addition, the government also needs to pursue poverty alleviation programs such as subsidizing cash assistance for student in poverty.
\end{abstract}

Keywords: government budget on education, education success, poverty

JEL Classification: H52, I25, I38

\section{Satu Dekade Anggaran Pendidikan 20 Persen: Bagaimana Kausalitas Antara Keberhasilan Pendidikan dan Kemiskinan?}

\begin{abstract}
ABSTRAK
Tahun 2019 tepat satu dekade anggaran pendidikan di Indonesia (pusat maupun daerah) dialokasikan sebesar 20 persen. Tujuan penelitian ini adalah untuk menganalisis hubungan kausalitas antara anggaran bidang pendidikan, keberhasilan pendidikan (diproksi dengan ratarata lama sekolah), dan kemiskinan (diproksi dengan jumlah penduduk miskin) di Indonesia. Data yang dianalisis merupakan data sekunder, tepatnya data panel dari 34 provinsi di Indonesia dalam kurun waktu lima tahun (2015-2019). Teknik analisis yang digunakan adalah Granger Causality Test. Hasil penelitian menunjukkan bahwa anggaran bidang pendidikan berpengaruh signifikan terhadap rata-rata lama sekolah, serta memiliki hubungan kausalitas dengan kemiskinan. Sedangkan kemiskinan terbukti mempengaruhi rata-rata lama sekolah.
\end{abstract}


Berdasarkan hasil analisis tersebut direkomendasikan bagi pemerintah agar tetap konsisten memprioritaskan anggaran untuk bidang pendidikan karena telah terbukti berdampak terhadap keberhasilan pendidikan dan kemiskinan. Selain itu pemerintah juga perlu mengupayakan program pengentasan kemiskinan seperti subsidi bantuan tunai bagi pelajar dari keluarga miskin.

Kata kunci: anggaran pendidikan, keberhasilan pendidikan, kemiskinan Klasifikasi JEL: H52, I25, I38

\section{INTRODUCTION}

The Sustainable Development Goals (SDGs), also known as global goals, were adopted by all member states of the United Nations (UN) in 2015 as a universal call to act to end poverty, protect the planet and ensure that all people will have peace and prosperity by 2030 (www.id.undp.or).

Indonesia is a developing country that will soon become a developed country so it is very serious in realizing the SDGs. Indonesia is also one of the countries with the largest population in the world, and in 2045 it is predicted that there will be a demographic bonus in Indonesia (Wisnumurti et al., 2018). The demographic bonus is a condition in which the dependency ratio is low as a result of the high number of people at productive age (15-64 years) when compared to the population at nonproductive ages $(<15$ years and $>64$ years). The demographic bonus can be an opportunity for the development of a country because the availability of labor will be greater. However, the demographic bonus can also become a burden if the population of productive age does not have the quality to carry out economic activities.

Education is a factor that really determines the quality of the nation's generation. The provision of education requires at least the cost of fulfilling the financing to provide service standards. However, the education process cannot run without money, so there needs to be support from the government, such as the APBD for education (Nandani et al., 2018).

The 1945 Constitution of the Republic of Indonesia in Article 31 paragraph (4) mandates the allocation of an education budget of 20 percent, either through 
central government budget intervention through the State Budget (APBN) or the Regional Revenue and Expenditure Budget (APBD). Since 2009, the government has begun to allocate a large amount of the education budget. During the period 2009-2014, the education budget allocation was the second largest budget portion of the expenditure in the APBN, after subsidies. Meanwhile, since 2015, the education budget has become the largest government expenditure.

The Indonesian government took concrete actions to guarantee education financing by issuing Law Number 20 of 2003 concerning the National Education System. In Article 49 Paragraph 1 of Law Number 20 Year 2003, it is stated that "Education funds are other than teachers' salaries and the State Budget (APBN) for the education sector and at least $20 \%$ of the APBD". When the education budget is adequate, then the next challenge is the distribution and utilization of education funds to suit needs, standards, and be able to have a real impact on realizing quality education.

The results of an empirical study from Gupta (2002) states that the increase in government spending in the education sector is directly proportional to access to education and the increase in students. An increase in the share of education sector spending also has a significant effect on increasing the achievement of educational performance which is proxied by the average length of schooling (Bado and Hasbiah, 2017).

Education and poverty are the main focus of the SDGs, and as a form of the government's political commitment to implement the SDGs, the President of the Republic of Indonesia (Joko Widodo) has signed Presidential Regulation Number 59 of 2017 concerning the Implementation of Achieving the Sustainable Development Goals. Therefore, the issues of poverty and education are very relevant to be studied in Indonesia.

2019 is a decade of education budget allocation of 20 percent, therefore this 
study aims to analyze the causality between the education budget, education success, and poverty in Indonesia. Moreover, several other studies regarding the education sector budget in several regions show that the impact of the education sector budget has not been optimal. As the results of research by Arifin and Murjani (2017) in South Kalimantan, it is stated that although government spending on the education and health sectors has a positive effect on HDI, this effect is relatively small, and this can indicate that the sector's spending is not optimal, both in terms of allocation and use.

\section{LITERATURE REVIEW}

\section{Education}

Education is an effort to guide children from birth to reach physical and spiritual maturity, in the interaction of nature and its environment (Nurkholis, 2013). The measurement of educational success has been measured by the average length of schooling.

The average length of schooling is the average number of years spent by the population aged 15 years and over across all levels of formal education attended. The average length of schooling indicates the higher level of formal education achieved by the people of an area. The higher the average length of schooling, the higher the level of education undertaken. To increase the average length of schooling, the Indonesian government has launched 9 (nine) years compulsory education program or basic education to junior high school level.

To get a job offered in the modern sector is based on a person's level of education, and the level of income one has during life has a positive correlation with the level of education. This level of income is greatly influenced by the length of time a person has received education (Todaro, 2000). The average length of schooling is an indicator of the level of education in an area. Education is a form of human capital that shows the quality of Human Resources (HR).

Figure 1 provides an illustration of expected personal income/benefits and actual personal costs associated with one's education level then completed (in 
years). The higher a person's education level, the faster the expected income increase, greater than the personal costs that must be incurred. To be able to maximize the difference between expected benefits and estimated costs, the optimal strategy for someone is to try to complete education as high as possible (Todaro, 2000).

Figure 1: Personal Income and Expense Curves

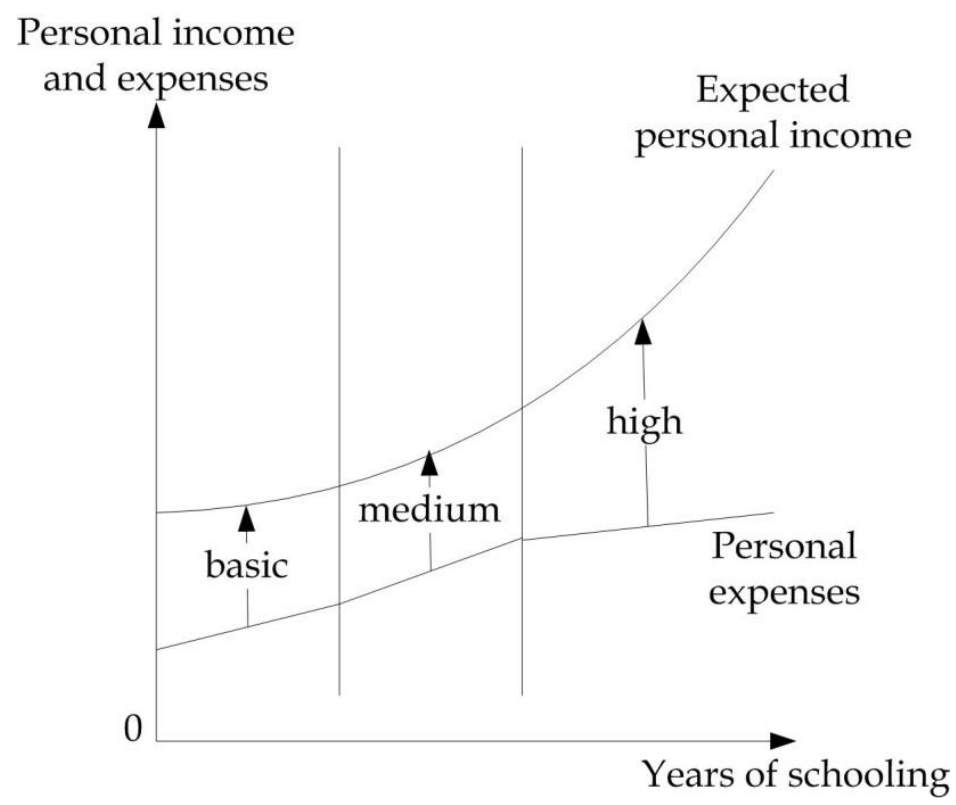

(Source: Todaro, 2000)

Government Expenditure (Education government spending for the purchase Sector) of goods and services; (2) government

Government spending is a budget allocation prepared in the APBN and $A P B D$ in various sectors with the aim of realizing public welfare with government programs (Arifin and Murjani, 2017). In macroeconomic theory, government spending consists of three main posts, namely: spending on employee salaries; and (3) government spending for transfer payments (Boediono, 1999).

Government expenditure in real terms can be used as an indicator of the size of government activities financed by government spending. The bigger and the more government activities, the 
greater the government expenditure concerned (Suparmoko, 1987).

With regard to government spending in the education sector as regulated in Government Regulation (PP) Number 38 of 2007 concerning the division of government affairs between the central government, provincial government and district/city governments, it is stated that the education sector budget in districts/cities is the expenditure budget used. to provide educational services in accordance with the mandatory affairs of the district/city government (Bado and Hasbiah, 2017).

\section{Poverty Theory}

According to the Indonesian Central Bureau of Statistics, poverty is the inability to meet the minimum standard of basic needs which includes food and non-food needs. Poverty can be measured by comparing the level of a person's consumption with the poverty line or the amount of rupiah spent on people's consumption per month. Basically, the definition of poverty can be seen from two sides, namely absolute poverty and relative poverty.
According to Todaro (2000) states that variations in poverty in developing countries are caused by several factors, namely: (1) geographic differences, population and income levels, (2) historical differences, some were colonized by different countries, (3) differences in source wealth natural resources and the quality of human resources, (4) differences in the roles of the private sector and the state, (5) differences in industrial structure, (6) differences in the degree of dependence on the economic and political power of other countries and, (7) differences in power distribution, political structures and domestic institutions.

Meanwhile, according to Jhingan (1992), there are three main characteristics of developing countries which are both causes and consequences of poverty which are interrelated. First, inadequate educational infrastructure and facilities, resulting in a high number of illiterate people who do not have skills or expertise. Second, poor health facilities and consumption patterns, so that only a small portion of the population can 
become productive workers. Third, the population is concentrated in the agricultural and mining sectors with outdated and outdated production methods.

According to Meier and Baldwin (in Jhingan, 1992) underdeveloped countries are generally entangled in what is called a "vicious cycle of poverty". 
Figure 2: A Vicious Circle of Human Underdevelopment

Market imperfection

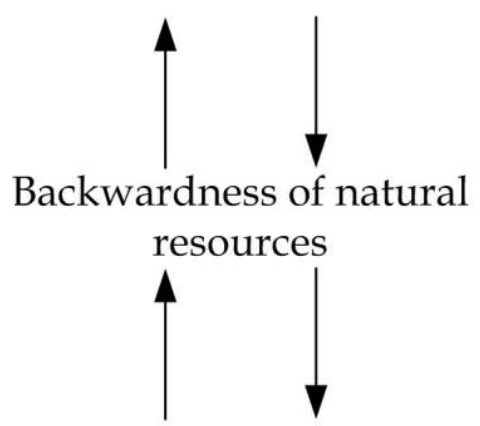

Backwardness of human

(Source: Jhingan, 1992)

Figure 2 shows that this vicious cycle is caused by underdevelopment of humans and natural resources. The development of natural resources in a country depends on the productive capabilities of its people. If the country's population is underdeveloped and illiterate, there is scarcity of technical skills, knowledge and entrepreneurial activities, then the existing natural resources will remain neglected, lacking or even misused. On the other hand, this underdevelopment of natural resources causes human backwardness. Underdevelopment of natural resources is both a cause and a result of human backwardness.

Research Framework
Bado and Hasbiah's (2017) research on the growth of education sector spending in South Sulawesi found that an increase in the share of education sector spending has a significant effect on increasing education performance achievement proxied by the average length of schooling. Likewise, Rony's research (2016) on the analysis of the determinants of the average length of schooling in West Kalimantan Province also found that the number of teachers and the education budget had a significant effect on the average length of schooling.

The results of research by Afzal et al. (2010) on the relationship between education and poverty show that there 
is a causal relationship between education and economic growth, economic growth and poverty, poverty and education. Likewise the research of Knight et al. (2008) who found that poverty affects the quality and quantity of education which in turn contributes to poverty. In addition, it was also found that the level of education causes differences in household income and also has an impact on poverty (Suasih et al., 2020).

Poverty makes poor people unable to take many opportunities, including educational opportunities, and this is caused by an imbalance in the social structure of society. Faturochman and Ambar (2011) explain that there is a kind of "vicious circle" between educational success and poverty, which means that education for the poor is not optimal because they are poor, otherwise they will remain poor because it is not optimal in education.

Widyastuti's (2012) research results also show a significant causal relationship between education and poverty. A prosperous family will be able to provide opportunities for family members to obtain a high level of education, so that it will bring more prosperity. The level of education certainly determines the skills possessed by the workforce. Samirin (2014) explains that one of the causes of the high number of unemployed is the large gap between the knowledge and skills of the workforce and the skills needed. This gap is usually experienced by those who do not have access to quality education.

According to the results of previous research conducted by Afzal et al., (2010) entitled "The Relationship Between Education, Poverty and Economic Growth in Pakistan: Econometric Analysis Method" TodaYamamoto Granger Causality Augmented (TYAGI) method, there is a cause for the relationship between education and growth. economy, economic growth and poverty, poverty and education. The study also recommends that the government should reduce poverty and improve education. The results of Afzal's study 
are also supported by the results of research and Knight et al. (2008) entitled "Education and the Poverty Trap in Rural China" found that poverty has a detrimental effect on the quality and quantity of education. which contributes to the poverty trap. Furthermore, when viewed from the influence of education, The conceptual framework of this research is presented in Figure 3.

Figure 3: Research Conceptual Framework

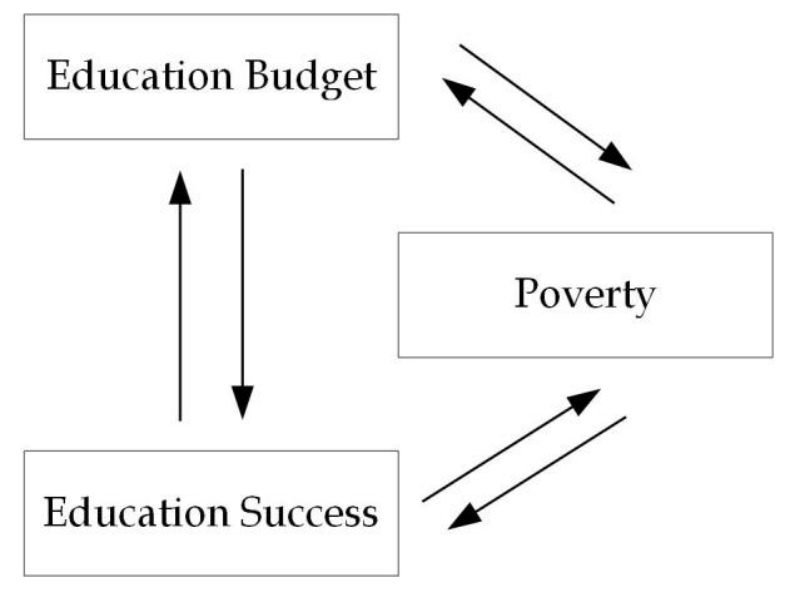

Based on the research conceptual framework and the results of previous studies, a research hypothesis can be made that the education budget, educational success, and poverty have a significant causal relationship.

\section{METHOD}

This research is a quantitative study using secondary data. Secondary data used comes from the Central Statistics Agency (BPS) of the Republic of Indonesia and the Regional Education Balance (Ministry of Education and
Culture). Secondary data used is panel data, namely data from 34 provinces in Indonesia with the data period 20152019. The data analysis technique used the Granger Causality Test (Batubara and Saskara, 2015), which was preceded by a unit root test and a lag length test.

The causality relationship is a shortterm relationship between certain groups using an econometric approach that includes a reciprocal relationship (Fauzi, 2007). With the optimal lag length, $p$, the Granger causality test 
working principle on panel data is follows. based on the pooled regression model as $y i t=a_{0}+a_{1} y_{i(t-1)}+\ldots+a_{p} y_{i(t-p)}+\beta_{1} x_{i(t-1)}+\ldots+\beta_{p} x_{i(t-p)}+\varepsilon_{i t}$

$x i t=a_{0}+a_{1} x_{i(t-1)}+\ldots+a_{p} x_{i(t-p)}+\beta_{1} y_{i(t-1)}+\ldots+\beta_{p} y_{i(t-p)}+\varepsilon_{i t}$

In the first pooled model regression equation (1), $\mathrm{X}$ affects $\mathrm{Y}$ or the one-way causality relationship from $\mathrm{X}$ to $\mathrm{Y}$ if the coefficient $\beta p$ is not equal to zero (0). Likewise for the second pooled model regression equation (2), $\mathrm{Y}$ affects $\mathrm{X}$ or there is a one-way causality relationship from $Y$ to $X$ if the coefficient $\beta p$ is not equal to zero. Meanwhile, if both occur, it is said that there is a reciprocal relationship (feedback relationship) between $\mathrm{X}$ and $\mathrm{Y}$ or there is a two-way causality (bidirectional causality) between $\mathrm{X}$ and $\mathrm{Y}$.

In this study, the Granger causality test was conducted to analyze the relationship between education budget variables, educational success, and poverty in panel data. The analysis was carried out using econometric software (Eviews), the null hypothesis used was:

1) The education budget does not affect the success of education and the success of education does not affect the education budget.

2) The education budget does not affect poverty and poverty does not affect the education budget.

3) The success of education does not affect poverty and poverty does not affect the success of education.

The basis for rejection of the null hypothesis is by using a probability criterion smaller than $0.1(<0.1)$.

\section{RESULTS AND DISCUSSION}

\section{Unit Root Test}

Before carrying out the Granger Causality Test, a unit root test is carried out so that the data becomes stationary. In addition, it can also be seen whether the data contains unit roots or not. If the variable contains unit roots, then the data is said to be non-stationary.

Table 1 shows that the probability value for all test methods is smaller than the critical value of 0.01 . So it can be said 
that the data on each of the research variables has been stationary at first level differentiation and the null hypothesis is rejected.

Table 1: Unit root test results

\begin{tabular}{lrrr}
\hline \multirow{2}{*}{ Method } & \multicolumn{3}{c}{ Variable } \\
\cline { 2 - 4 } & $\begin{array}{c}\text { Education Sector } \\
\text { Budget }\end{array}$ & $\begin{array}{c}\text { Educational } \\
\text { Success }\end{array}$ & Poverty \\
\hline Levin, Lin \& Chu t ${ }^{*}$ & $-42.9975^{* * *}$ & $-20,5309^{* * *}$ & $-26,3530^{* * *}$ \\
ADF - Fisher Chi-square & $(0.0000)$ & $(0.0000)$ & $(0.0000)$ \\
& $110,725^{* * *}$ & $125,019^{* * *}$ & $148,744^{* * *}$ \\
PP - Fisher Chi-square & $(0.0000)$ & $(0.0000)$ & $(0.0000)$ \\
& $126,989^{* * *}$ & $136,730^{* * *}$ & $162,101^{* * *}$ \\
& $(0.0000)$ & $(0.0000)$ & $(0.0000)$ \\
\hline
\end{tabular}

Data source: BPS RI and Kemdikbud RI

${ }^{*} p<0.1 * * p<0.05 * * * p<0.01$

Lag Length Test

Granger causality test need to pay attention to determining the lag length. The lag length must be correct because it is important to avoid misspecified models due to the lag length being too short, or reducing the degree of freedom too long. Lag testing using the Eviews application can make it easier to determine the right lag length. So that good and correct data results can be obtained. In Eviews, determining the optimal lag is by looking at the sign $\left(^{*}\right)$ at the most for each lag option. Table 2 shows the results of the lag length test in the research model.

Table 2: Result of the lag length test

\begin{tabular}{ccccccc}
\hline Lag & LogL & LR & FPE & AIC & SC & HQ \\
\hline 0 & $-1265,756$ & NA & $3.23 e^{+12}$ & 37.31635 & 37,41427 & 37,35515 \\
1 & $-781,2992$ & 911,9187 & 2728074, & 23.33233 & 23,72401 & 23,48752 \\
2 & $-745,0511$ & 65,03344 & 1226258, & 22.53091 & $23,21635^{*}$ & 22,80250 \\
3 & $-731,2963$ & $23,46409^{*}$ & $1070760,^{*}$ & $22.39107^{*}$ & 23,37026 & $22,77905^{*}$ \\
\hline
\end{tabular}

Data source: BPS RI and Kemdikbud RI

Note: * shows the lag order selected by the criterion

LR: sequential modified LR test statistic (test at 0.05 level)

FPE: Final prediction error

AIC: Akaike information criterion

SC: Schwarz information criterion

HQ: Hannan-Quinn information criterion 
Based on the output shown in Table 2, the optimal lag according to the LR, FPE, AIC, and HQ criteria is the smallest and most $\left({ }^{*}\right)$ shown in lag 3 .

Granger Causality Test
Granger causality test is used to see the direction of the relationship between education and poverty. Whether there is a relationship can be seen from the probability value of each causality test which is then compared with alpha 0.1.

Table 3: Granger causality test results

\begin{tabular}{|c|c|c|c|}
\hline Null Hypothesis & F-statistik & Probability & Result \\
\hline GBE does not affect MYS & 5,48110 & 0,0021 & $\begin{array}{l}\text { The null hypothesis is } \\
\text { rejected }\end{array}$ \\
\hline MYS does not affect GBE & 0,89695 & 0,4480 & $\begin{array}{l}\text { The null hypothesis is } \\
\text { accepted }\end{array}$ \\
\hline GBE does not affect POV & 2,38834 & 0,0775 & $\begin{array}{l}\text { The null hypothesis is } \\
\text { rejected }\end{array}$ \\
\hline POV does not affect GBE & 8,28255 & 0,0001 & $\begin{array}{l}\text { The null hypothesis is } \\
\text { rejected }\end{array}$ \\
\hline MYS does not affect POV & 1,78581 & 0,1593 & $\begin{array}{l}\text { The null hypothesis is } \\
\text { accepted }\end{array}$ \\
\hline POV does not affect MYS & 2,25242 & 0,0912 & $\begin{array}{l}\text { The null hypothesis is } \\
\text { rejected }\end{array}$ \\
\hline
\end{tabular}

Data source: BPS RI and Kemdikbud RI

Note: GBE: government budget on education/education budget MYS: mean years of schooling/ educational success (average length of school) POV: poverty/ poverty (number of poor people)

Based on the output of Table 3 shows that:

1) The education budget statistically significantly affects the success of education, which is indicated by a probability value of $0.0021<a=0.1$ on lag 3. However, the success of education does not statistically significantly affect the education budget, which is indicated by a probability value of $0.4480>a=0.1$ on lag 3. Thus, it can be concluded that the Granger causality test has one way relationship between education budget and educational success. 
2) The education budget statistically significantly affects poverty, which is indicated by a probability value of $0.0775<\mathrm{a}=0.1$ on lag 3. Likewise, poverty is statistically significant in affecting the education budget, which is indicated by a probability value of $0.0001<\alpha=0.1$ at lag 3 . Thus, it can be concluded that the Granger causality test has a two-way relationship between the education budget and poverty.

3) The success of education statistically does not significantly affect poverty, which is indicated by a probability value of $0.1593>a=0.1$ at lag 3 . While poverty is statistically significant in affecting the success of education, which is indicated by a probability value of $0.0912<\alpha=0.1$ at lag 3. Thus, it can be concluded that the Granger causality test has a one-way relationship between educational success and poverty.

\section{Discussion}

Based on the results of hypothesis testing, it is found that the education budget in Indonesia has a significant effect on the success of education which is proxied by the average length of schooling.

The education budget, which has been allocated the highest ( 20 percent) for a decade by the government, is carried out to ensure that all Indonesian people get access to education which is their right. Education is calculated as a determining factor for one's success, both socially and economically (Schuktz, 1961).

The results of this study also indicate that the education budget on educational success occurs 3 (three) years after the budget year (three years lag).

Ilhami (2014) in his research states that there is a positive linear relationship between the percentage increase in the per capita education budget for school age and the percentage increase in the Human Development Index (HDI). Where education is one of the HDI determining variables which can be assessed one of them from the average length of schooling. Meanwhile, the current average length of schooling has 
not been taken into account in determining the education budget allocation. In fact, by assessing the average length of schooling, it can be used as material for evaluating the education budget of a region.

The education budget is also statistically proven to have a causal relationship with poverty. Policies in the education budget sector should cover the costs incurred by parents of students because of the mandate of the 1945 Constitution, education should be free (Kamsol et. Al, 2014). Kamsol et al (2014) explained that in the basic concept of education financing, there are two important things that need to be studied, namely the overall cost (total cost) and the unit cost per student (unit cost). Research results by Kamsol et. al (2014) regarding the budget and cost of education in Riau found that parents of students spent more non-education costs at the SD (elementary school), SMP (junior high school), and SMA/SMK (senior high school) levels, such as building donations, routine tuition, tutoring, study tours, and others.

The use of the education budget is influenced by the economic conditions of students and the region concerned. This is because the government has not regulated the allocation of the budget in detail according to regional characteristics.

Based on the results of hypothesis testing, it is found that poverty has a significant effect on the success of education in Indonesia. In line with the results of previous research conducted by Sesmiati (2009) which found that parents' income had a significant and negative effect on the drop out rate in Kenagarian Batu Plano. Likewise, Izzaty's research (2009) states that poverty has a significant and negative effect on educational equality. Todaro and Smith (2004) state the theory that "people because of poverty are unable to continue their education will be in the group of people who have dropped out of school or are uneducated". 


\section{CONCLUSION}

Based on the results of data analysis, it can be concluded that statistically, the education budget has a significant effect on the success of education.

Furthermore, it is also evident that the education budget has a causal relationship with poverty. Meanwhile, poverty is proven to affect the success of education in Indonesia.

As a follow-up to the research results, it is recommended that the government conduct an evaluation of the outputoriented education budget planning, one of which is through an evaluation of the average length of schooling. The budget that has been made so far is dominant to meet school needs and teacher fees. In addition, several education fund programs, such as School Operational Assistance (BOS) throughout Indonesia, are still uniform in number, even though the needs and conditions in each region in Indonesia are certainly not the same. In addition, considering that there are noneducational costs that students' parents also need to prepare, the government should provide cash assistance for students from poor families to prevent dropping out of school, increase the average length of schooling, and reduce expenses for poor families.

\section{REFERENCES}

Afzal, M., Malik, M.E., Begum, I., Sarwar, K., Fatima, H. (2010). Relationship among education, poverty and economic growth in Pakistan: An econometric analysis. Journal of Elementary Education, 22(1),23-45.

Arifin, B., Murjani, A. 2017. Pengeluaran Pemerintah Daerah pada Sektor Pendidikan, Kesehatan dan Kemiskinan Terhadap Indeks Pembangunan Manusia (Studi pada Kabupaten/Kota di Provinsi Kalimantan Selatan). Jurnal Transformasi Administrasi, 07(02), 1352-1368.

Bado, B., Hasbiah, S. 2017. Analisis Pertumbuhan Belanja Sektor Pendidikan Terhadap Capaian Rata-rata Lama Sekolah di Sulawesi Selatan. Jurnal Economix, 5(1), 238-249.

Faturochman, Widaningrum, A. (2011). Pendidikan untuk kaum kecil. Research center of population. UGM.

Izzaty. 2009. Faktor-faktor yang mempengaruhi partisipasi sekolah anak jenjang SMP dan SMA di Sumatera Barat. Jurnal 
Jhingan, M. L. 1992. Ekonomi Pembangunan dan Perencanaan. Rajawali, Jakarta.

Knight, J., Shi, L., Quheng, D. 2008. Education and the Poverty Trap in Rural China. CSAE Working Paper Series 2008-02, Centre for the Study of African Economies, University of Oxford.

Kamsol, Maryunani, Susilo, Gozali. 2014. Analysis of Education Financial Restructuring Strategies to Increase Human Resource Quality in Riau Province. IOSR Journal of Economics and Finance, 2(4), 4555.

Nandani, S. C. D., Setyadin, B., Nurabadi, A. 2018. Analisis Alokasi Anggaran Pendidikan Dalam Anggaran Pendapatan Belanja Daerah. Jurnal Administrasi dan Manajemen Pendidikan, 1(1), 22-28.

Nurkholis. 2013. Pendidikan dalam Upaya Memajukan Teknologi. Jurnal Kependidikan, 1(1), 24-44.

Rony, M. 2016. Analisis Determinan Rata-rata Lama Sekolah Kabupaten/Kota di Propinsi Kalimantan Barat Tahun 20092015. Jurnal Curvanomic, 5(4).

Samirin, W. 2014. Mengurangi ketimpangan, meluruskan esensi pembangunan. Presented in scientific papers, in order to anniversary-16, Paramadina University, Jakarta, 10 January 2014.
Sesmiati. 2009. Faktor-Faktor yang Mempengaruhi Drop Out di Kenagarian Batu Plano Kecamatan Sungai Pua, Kabupaten Agam. Skripsi. UNP

Todaro, M., Smith, S. 2004. Pembangunan Ekonomi di Dunia Ketiga. Edisi kedelapan. Jakarta: Erlangga.

Todaro, Michael P. 2000. Pembangunan Ekonomi di Dunia Ketiga. Erlangga. Jakarta.

Widyastuti, A. (2012). Analisis hubungan antara produktivitas pekerja dan tingkat pendidikan pekerja terhadap kesejahteraan keluarga di Jawa Tengah Tahun 2009. Vol. 1 No. 1. pp.1-11.

Wisnumurti, A.A.G.O., Darma, I K., Suasih, N.N.R. (2018). Government Policy of Indonesia to Managing Demographic Bonus and Creating Indonesia Gold in 2045. IOSR Journal of Humanities and Social Science, 23(1), 23-34. 